\title{
Quality of cellular attachment to various root-end filling materials
}

\author{
Ahmad S. AL-HIYASAT ${ }^{1}$, Oula R. AL-SA'EED ${ }^{2}$, Homa DARMANI ${ }^{3}$ \\ 1- BDS, MScD, PhD, Department of Conservative Dentistry, Faculty of Dentistry, Jordan University of Science and Technology, Irbid, Jordan. \\ 2- BDS, MSc, Department of Conservative Dentistry, Faculty of Dentistry, Jordan University of Science and Technology, Irbid, Jordan. \\ 3- BSc, FIMLS, PhD, Department of Biotechnology and Genetic Engineering, Faculty of Science, Jordan University of Science and Technology, Irbid, Jordan.
}

Corresponding address: Professor Ahmad S. Al-Hiyasat - Department of Conservative Dentistry - Faculty of Dentistry, Jordan University of Science \& Technology - P.O. Box 3030 - Irbid 22110 - Jordan - Phone: +962-795-843677 - Fax: +962-2-7095115 - e-mail: hiyasat@just.edu.jo

Received: November 21, 2009 - Modification: March 22, 1010 - Accepted: May 30, 2010

\section{ABSTRACT}

\begin{abstract}
bjectives: This study investigated cellular attachment to 6 root-end filling materials as a measure of the biocompatibility of the materials. Material and Methods: Class I retrograde cavities were prepared in root slices and these cavities were filled with the test materials, and incubated with Balb/C 3T3 fibroblasts for $24 \mathrm{~h}$. Root slices with the cavities left empty served as the controls. The root slices were then processed for scanning electron microscopy, and were viewed to assess the quality of cellular attachment by observing the shape of cells, spread, and membrane outline. Results: The best cellular attachment was observed at MTA and Geristore surfaces: cells exhibited characteristic elongated fibroblastic morphology, with projections of lamellipodia, filopodia, blebs, and microvilli from their surfaces, reflecting good attachment to the material. Fibroblasts attached poorly to the surfaces of IRM, Super EBA, KetacFil and Retroplast. Furthermore, the cells did not attach well to the tooth structure next to IRM and Super EBA. Conclusions: The present study demonstrated a variation in cellular attachment to different root-end filling materials with the best cellular attachment to the surfaces of MTA and Geristore. IRM and Super EBA, Ketac Fil and Retroplast rendered poor attachment.
\end{abstract}

Key words: Biocompatibility testing. Cell adhesion. Electron microscopy. Endodontics. Dental materials. Fibroblasts.

\section{INTRODUCTION}

The aim of endodontic surgery is to preserve the tooth and to remove the periradicular pathosis and to restore health and function of tooth periodontium ${ }^{11,14}$. This includes curettage of the periapical pathosis, resection of the root end and the use of a root-end filling material to seal the root-end cavity.

Many materials have been used for root-end filling, including amalgam, gutta-percha, zinc oxideeugenol cements (Intermediate Restorative Material - IRM ${ }^{\circledR}$, Ethoxybenzoic acid cement Super EBA ${ }^{\mathrm{TM}}$ ), glass ionomer cement, gold foil pellets, Cavit, composite resin, and mineral trioxide aggregate (MTA $)^{10,17}$. Although MTA has been thoroughly examined nowadays with promising results ${ }^{12,19}$, unfortunately, the ideal root-end filling material is yet to be found.
Root-end filling materials are kept in contact with the periradicular tissues, thus requiring biocompatibility as the main property of such material. Thus, an ideal root-end filling material should be biocompatible, adherent to tooth structure, dimensionally stable, resistant to dissolution, antibacterial, radiopaque, and easy to use $^{10,17}$. Indeed, the biocompatibility of the root canal sealer plays a significant role in the success of endodontic treatment. A toxic, tissue necrotizing sealer may impair tissue healing or create a favorable local environment for microbial invasion and long-term failure.

In-vitro cytotoxicity tests represent the first stage of biocompatibility screening process, with different assays being used to assess the effects of a biomaterial on cell number, cell growth, cell membrane integrity, enzyme activity, or genetic effects $^{8}$. In addition, cell adhesion and spread over 
root-end filling materials has been suggested as an evaluation criterion ${ }^{24}$.

Indeed, fibroblast migration, attachment, and orientation are necessary steps for attachment regeneration, which is a prerequisite of the healing process following endodontic surgery ${ }^{22}$. As cellular attachment is the initial phase of cellular function, it has been considered a more sensitive indicator of cytotoxicity ${ }^{6,9}$. Thus, the aim of this study was to investigate the attachment of fibroblasts to rootend filling material surfaces, as a biocompatibility assessment of these materials.

\section{MATERIAL AND METHODS}

\section{Root-end filling materials}

Figure 1 shows details of the composition of the six root-end filling materials that were tested in the present study, namely: Retroplast ${ }^{\mathrm{TM}}$ (Retroplast Trading, Dybesøvej, Denmark); Geristore, PerioEndo kit (DEN-MAT Corporation, Santa Maria, CA, USA) shade A3.5; Ketac FilTM Plus (3M ESPE, Seefeld, Germany) shade A3; IRM ${ }^{\circledR}$ (Caulk-Dentsply, Milford, DE, USA); Super EBA (Bosworth Company, Skokie, IL, USA); PROROOT ${ }^{\circledR}$ MTA (Dentsply-Tulsa Dental, Johnson City, TN, USA) tooth-colored.

\section{Cell culture}

Fibroblasts derived from Balb/C mouse embryos [(Balb/C 3T3 mouse fibroblasts Clone A31 (European Collection of Cell Culture, Salisburg, Wilts, UK)] were routinely maintained in DMEM supplemented with $5 \%$ fetal bovine serum, $5 \%$ new born calf serum, 100 unit/mL penicillin, 100 unit/mL streptomycin and $0.25 \mu \mathrm{g}$ of amphotericin B (PAA Laboratories $\mathrm{GmbH}$, Linz, Austria) at $37^{\circ} \mathrm{C}$ in an atmosphere of $5 \% \mathrm{CO}_{2}$. They were routinely passaged by trypsinization.
Preparation of root slices for Scanning Electron Microscopy (SEM)

Extracted human teeth were collected and stored in $0.12 \%$ thymol. Roots selected were either from single-rooted teeth, distal roots of lower molars, or palatal roots of upper molars. Upon examination, roots with apical resorption or severe dilacerations, as well as roots that contained more than one canal foramen were all excluded. Prior to use, teeth were washed with tap water and tissue tags removed.

In order to be able to hold the teeth in the milling machine, each tooth was then mounted with its apex up, inside a plastic ring using self cure acrylic material (Meliodent, Heraeus, Kulzer GmbH \& Co, Senden, Germany). The ring was then secured to the tripod attachment of the milling machine (Paraskop M, BEGO, Bremer, Germany). The apical 3 $\mathrm{mm}$ of the root tips were cut using a 0.2-mm-thick diamond disc (Komet, GEBR, BRASSELER GmbH \& Co, Lemgo, Germany) at 15,000 rpm. A cavity was then prepared using the milling machine to a depth of $2 \mathrm{~mm}$ using a low-speed tungsten carbide fissure bur (No. 6233) (MEDIN, N. Mĕsto/Mor, Czech Republic). All cavities had a diameter of $1 \mathrm{~mm}$. Burs and discs used to prepare root slices were discarded after each group in order to ensure similar surface characteristics and standardization of all specimens. The root was then cut $4 \mathrm{~mm}$ coronal to the apical prepared surface using the diamond disc. Water cooling was used during root slice preparation and a total of 20 root slices were prepared, as described. Root slices were then sterilized by placing them in glass vials containing distilled water and autoclaved and stored until used. Cavities were filled with the root end filling materials using sterile instruments. The surface of the material was smoothed using plastic instruments and carvers. For each material, three specimens were prepared. Two root slices with the cavities described above were left empty and served as the controls.

Each root-end filling material specimen was

\begin{tabular}{|c|c|c|c|c|}
\hline Product name & Type & Presentation & Lot no. & Notes \\
\hline Retroplast $^{\mathrm{TM}}$ & Resin composite & Two pastes in syringes & 12 & \\
\hline Geristore & Resin-modified glass ionomer & Two pastes in jars & G327010038 & $\begin{array}{l}\text { Perio-Endo kit, } \\
\text { shade A3.5 }\end{array}$ \\
\hline Ketac Fil ${ }^{\mathrm{TM}}$ Plus & Glass ionomer cement & Powder and liquid & $\begin{array}{l}\text { Powder: } 215153 \\
\text { Liquid: } 185972\end{array}$ & Shade A3 \\
\hline $\mathrm{IRM}^{\circledR}$ & $\begin{array}{l}\text { Reinforced zinc oxide-eugenol } \\
\text { cement }\end{array}$ & Powder and liquid & 60215 & \\
\hline Super EBA & $\begin{array}{l}\text { Reinforced zinc oxide-eugenol } \\
\text { cement }\end{array}$ & Powder and liquid & $0602-055-X$ & Fast set \\
\hline PROROOT $^{\circledR}$ MTA & Portland cement derivative & $\begin{array}{l}\text { Powder and sterile } \\
\text { water ampoules }\end{array}$ & 5002015 & Tooth colored \\
\hline
\end{tabular}

Figure 1- Root-end filling materials tested in this study 
placed in a well of a 24-well tissue culture plate and $1 \mathrm{~mL}$ of cell suspension ( $5 \times 10^{5}$ cells $/ \mathrm{mL}$ ) was added over the specimen. Cells were incubated for $24 \mathrm{~h}$ at $37^{\circ} \mathrm{C}$ and $5 \% \mathrm{CO}_{2}$. At the end of the incubation period, the culture medium was aspirated, and the cells fixed with $1 \mathrm{~mL}$ of $2.5 \%$ glutaraldehyde in 0.1 M Sorensen's sodium phosphate buffer $(\mathrm{pH} 7.2)$ for $30 \mathrm{~min}$, followed by a brief wash with phosphate buffered saline. Specimens were dehydrated in a series of 30, 50, 70, 90 and 95\% ethyl alcohol and twice in absolute ethyl alcohol for $30 \mathrm{~min}$ before they were critical point dried with $\mathrm{CO}_{2}$ (CPD 030, Balzers, Wiesbaden, Germany). They were then

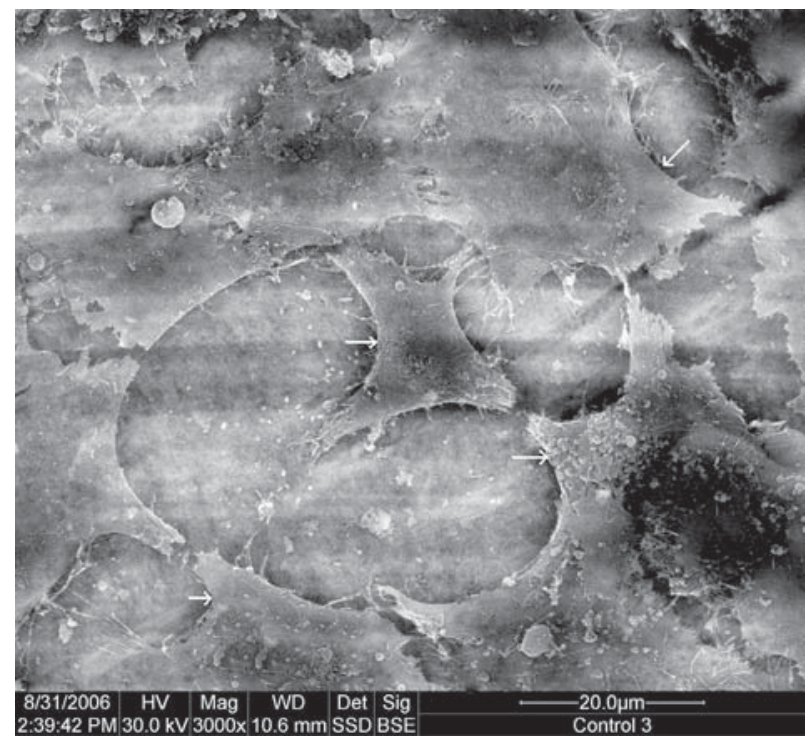

Figure 2- Scanning electron microscope (SEM) micrograph of control (original magnification 3,000x). Arrows indicate cells

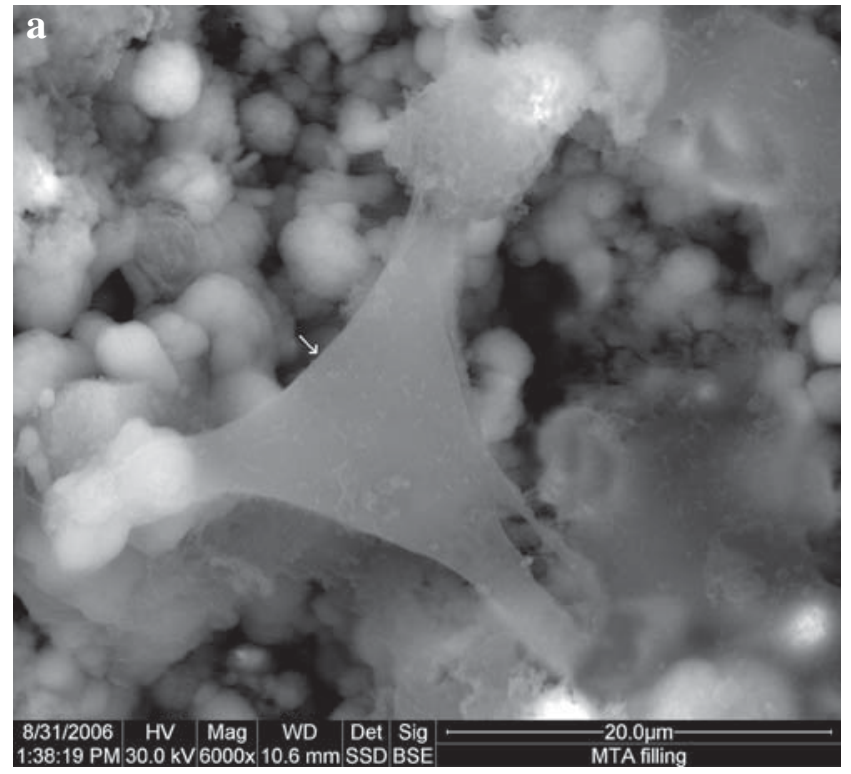

mounted on aluminum stubs and coated with gold in a vacuum coater (Polaron Division E6100, Bio-Rad, Birmingham, UK) at 1200 volts and 20 $\mathrm{mA}$. They were viewed carefully under a scanning electron microscope (Quanta 2000-FEI, Eindhoven, Netherlands) at an accelerating voltage of $30 \mathrm{kV}$. Several photomicrographs were taken to ensure that representative data were collected.

\section{Criteria for image analysis}

The image analysis was performed by one operator who was not blind to the study. Cell attachment was assessed by the presence of filopodia (cylindrical/conical processes, often 10-20 $\mu \mathrm{m}$ long with a small diameter); microvilli (the processes of smallest diameter, 0.1-0.2 $\mu \mathrm{m}$ ); lamellipodia (flat extensions, with their thickness reaching 0.1-0.5 $\mu \mathrm{m}$ ); Blebs (round extensions, their diameters ranging between 1-2 $\mu \mathrm{m}$ ).

\section{RESULTS}

\section{Control}

Cells attached well to root slices, observed in their flat shape, and their sheet-like spreading (Figure 2). All 4 types of cellular projections could be seen, as described previously.

\section{MTA}

The surface of the MTA showed flat, spindle shaped cells. Cells projected lamellipodia, filopodia, blebs, and microvilli from their surfaces. The root surfaces demonstrated a similar view, with more cellular process, and a higher cellular density (Figure 3).

Figure 3- Scanning electron microscope (SEM) micrograph of MTA: (a) material surface (original magnification 6,000x); (b) root surface (original magnification 3,000x). Arrows indicate cells 

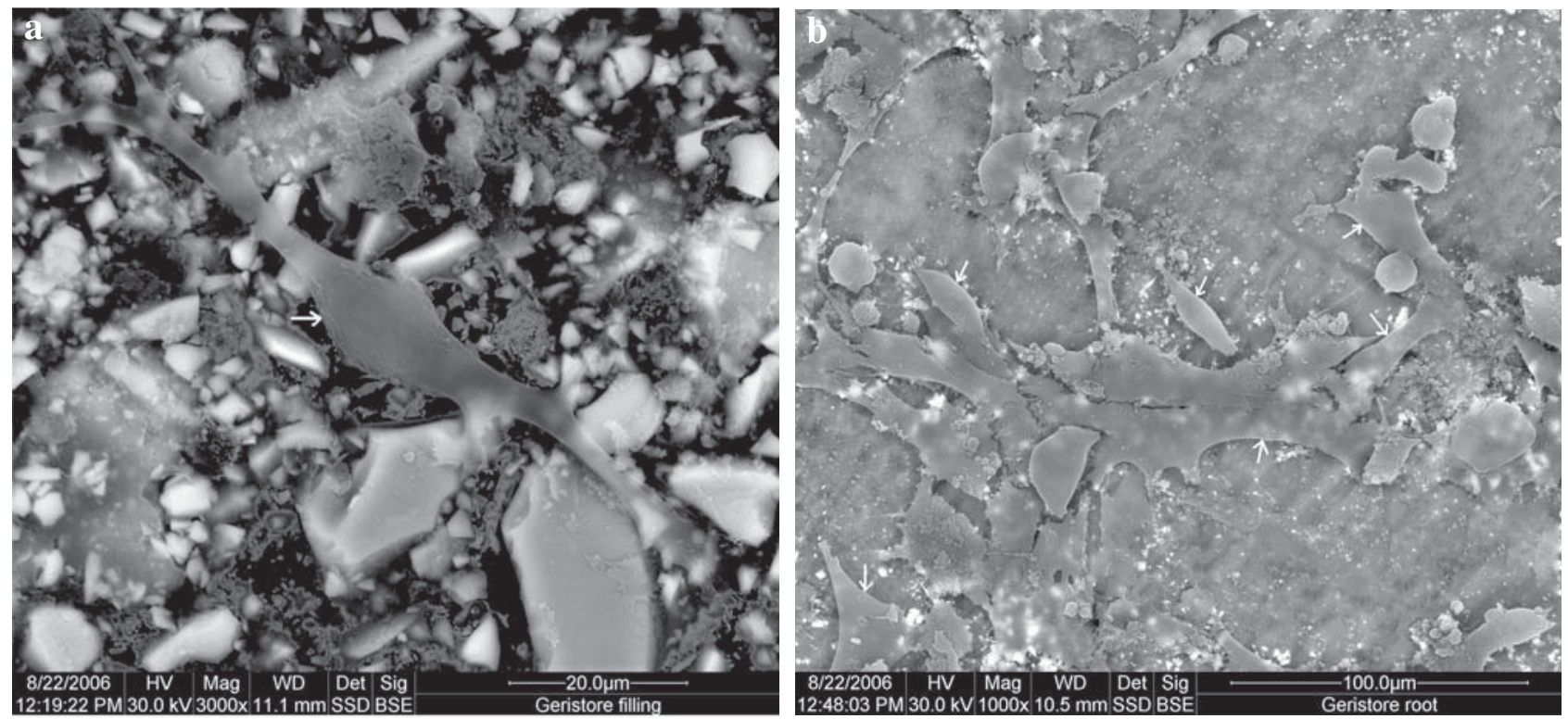

Figure 4- Scanning electron microscope (SEM) micrograph of Geristore: (a) material surface (original magnification $3,000 x$ ); (b) root surface (original magnification 1,000x). Arrows indicate cells
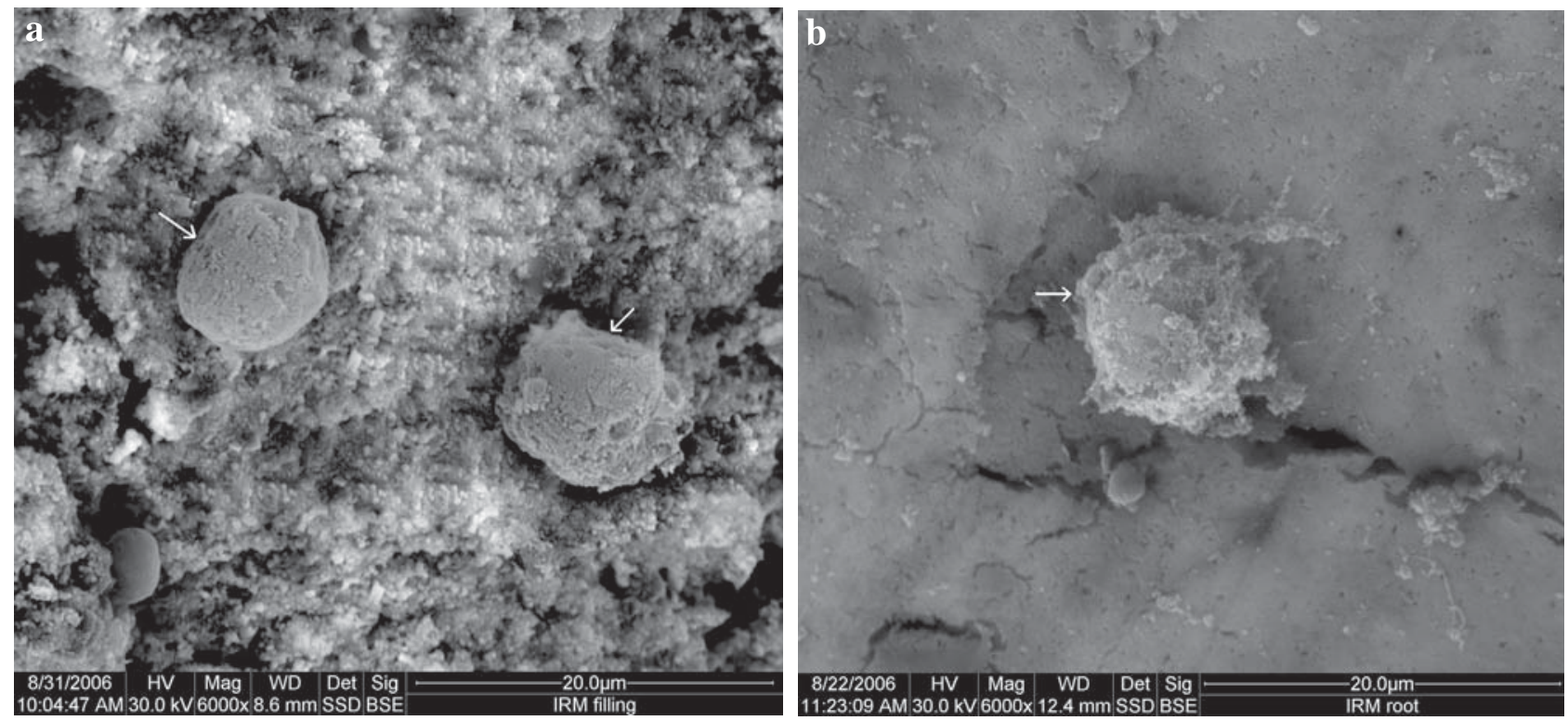

Figure 5- Scanning electron microscope (SEM) micrograph of IRM: (a) material surface (original magnification 6,000x); (b) root surface (original magnification 6,000x). Arrows indicate cells

\section{Geristore}

The cells on the surface of Geristore material were spindle shaped and well attached, with lamellipodia and filopodia, thus reflecting good attachment to the material. Root surfaces did not show differences from the material surfaces, having the same cell configuration and almost the same cellular density, when viewed at the same magnification (Figure 4).

\section{IRM}

The IRM material surface showed round cells with rough surfaces and numerous vacuoles and surface depressions. The root surfaces demonstrated a similar view to that of the material surface, however, with more irregularity of the cell shape. Microvilli and filopodia were occasionally seen on root surfaces (Figure 5 ).

\section{Super EBA}

A similar view to that of IRM was seen on the Super EBA material. Root surfaces also showed round cells with vacuoles, however, with less cellular processes compared to IRM root surfaces (Figure 6).

\section{Ketac Fil}

The surface of Ketac Fil showed very sparse cellular growth, with cells of round shape, and a 

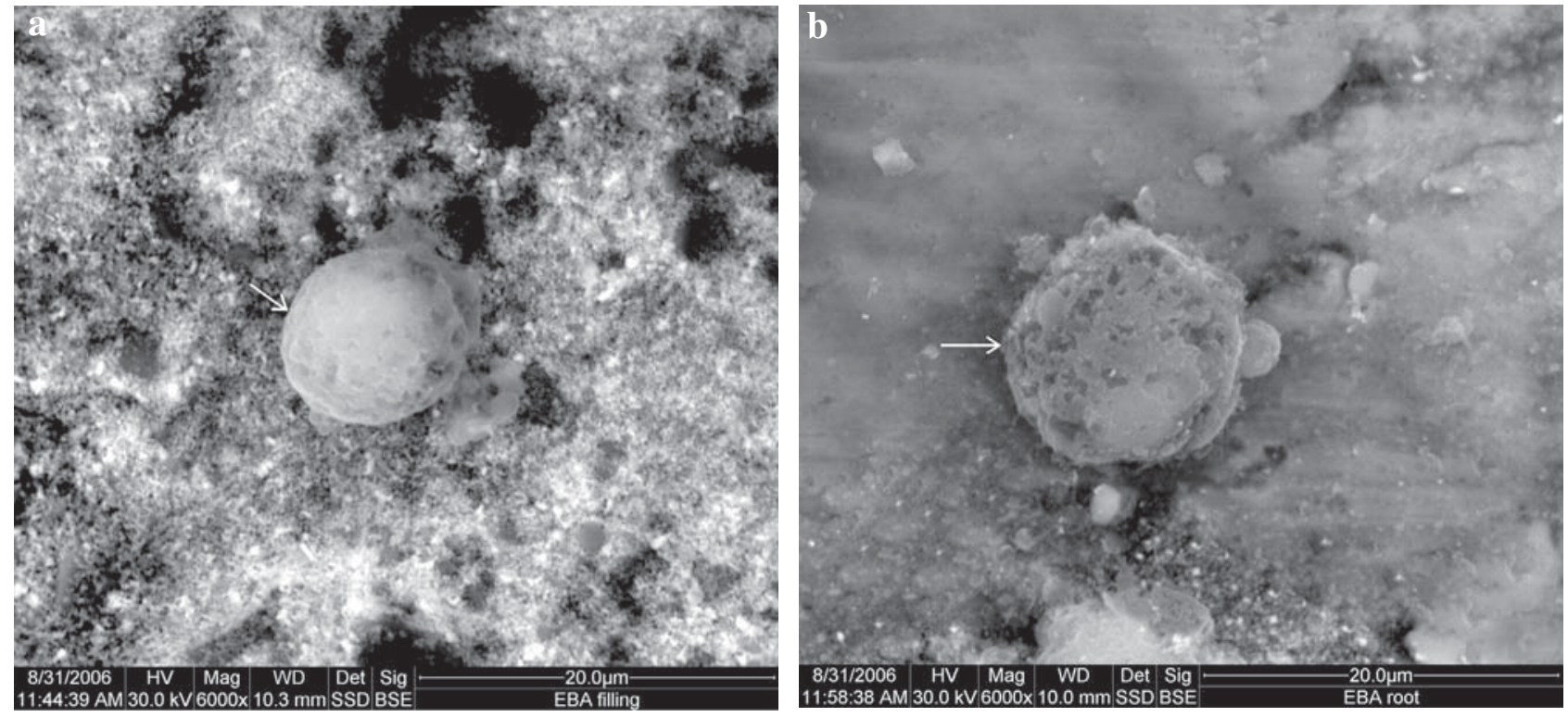

Figure 6- Scanning electron microscope (SEM) micrograph of Super EBA: (a) material surface (original magnification $6,000 x$ ); (b) root surface (original magnification 6,000x). Arrows indicate cells
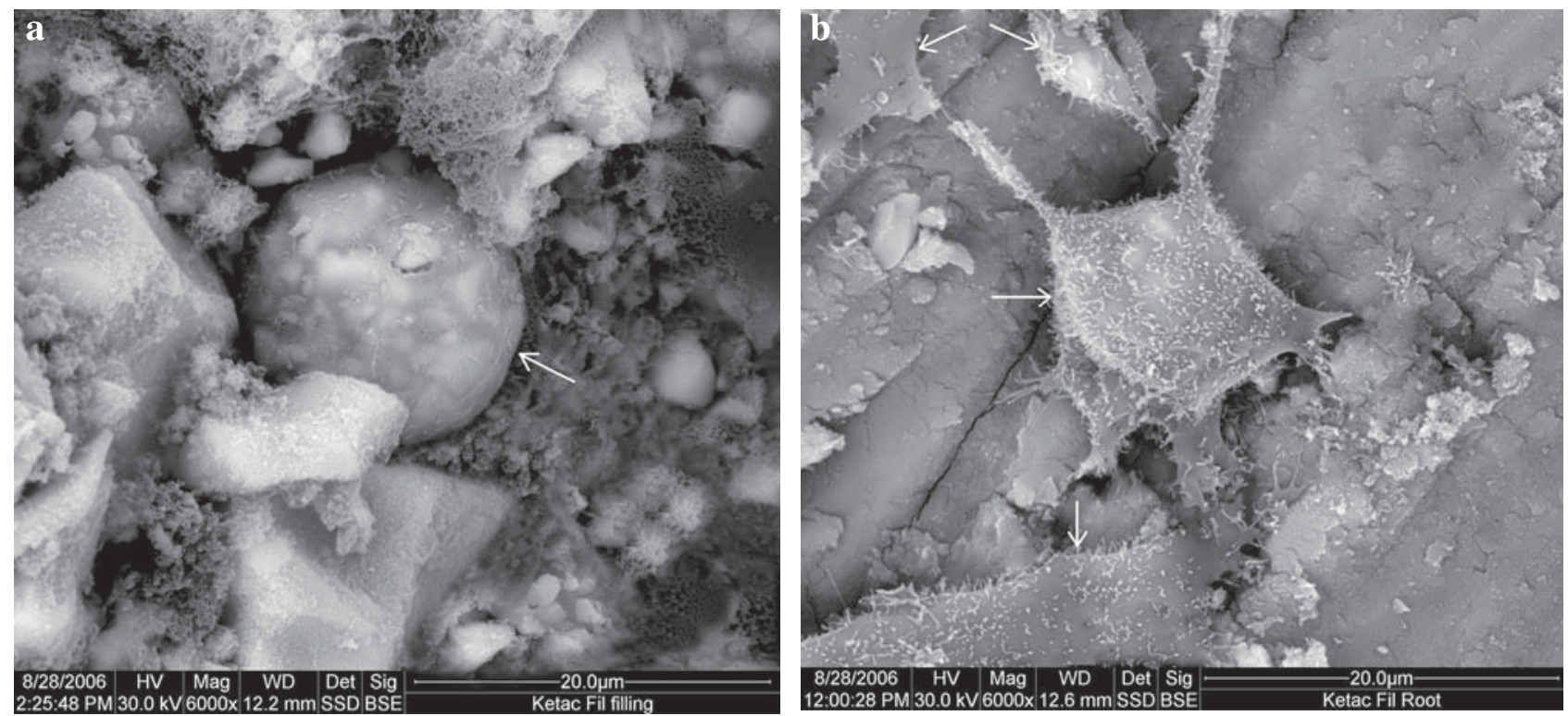

Figure 7- Scanning electron microscope (SEM) micrograph of Ketac Fil: (a) material surface (original magnification 6,000x); (b) root surface (original magnification 6,000x). Arrows indicate cells

rough surface due to the extending processes, namely microvilli. While on the root surface, cells demonstrated excellent attachment features including a spindle shape, lamellipodia, filopodia, and microvilli (Figure 7).

\section{Retroplast}

SEM micrographs of Retroplast specimens showed that fibroblasts did not adhere well to the material. They had a round structure with vacuoles and depression on their surfaces (Figure 8 ). However, the root surface of the Retroplast specimens showed that cells had attached well. Cells were spindle shaped, with blebs and lamellipodia extending from them (Figure 8).

\section{DISCUSSION}

Fibroblast attachment is an essential requirement for the formation of a new attachment apparatus to root surfaces following endodontic surgery ${ }^{22}$ and thus may be an important predictor of the success of surgical endodontic treatment. In the present study, attachment of cells was assessed qualitatively by SEM, which allows a close observation of cellular morphology and reaction to the filling material and this method has been used by several investigators ${ }^{2,4,5,15,16,24}$. 

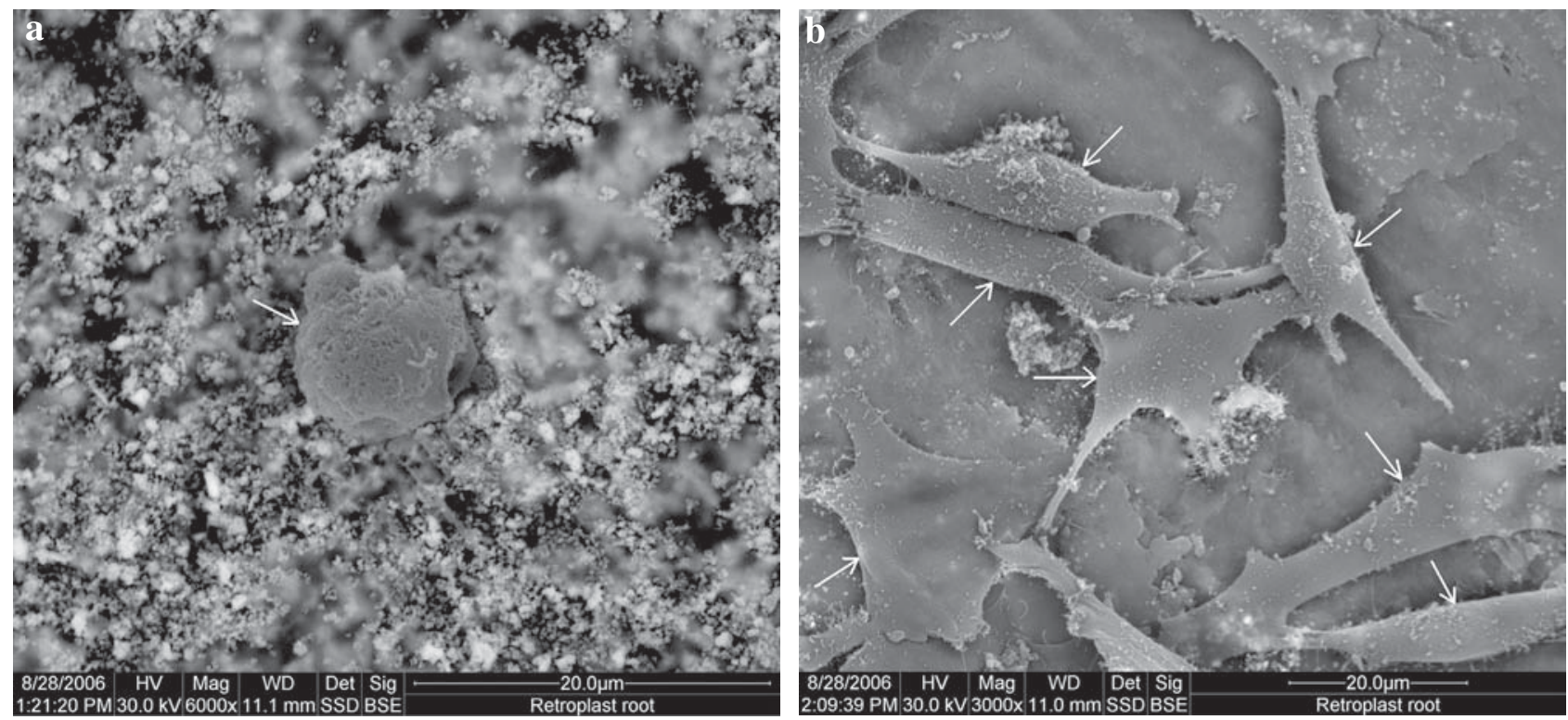

Figure 8- Scanning electron microscope (SEM) micrograph of Retroplast: (a) material surface (original magnification $6,000 x$ ); (b) root surface (original magnification 3,000x). Arrows indicate cells

Root slice specimens were used with the materials embedded within them to compare the cellular attachment to the materials as well as to the tooth structure itself. Cavity preparations were carried out using low speed fissure burs to a depth of $2 \mathrm{~mm}$. Root-end filling materials were then condensed into these cavities. This specimen design was adopted from a previous study ${ }^{5}$. It is easy to handle without disturbing the cell layer and allows a comparison between the cellular attachment to the material surface and to the root surface.

In the present study, root slices were autoclaved prior to incubation with cells. This is mandatory because the concentration of antibiotics present in the cell culture medium is insufficient to control contamination when human tooth root slices are used $^{1}$.

We found that the best cellular attachment occurred to the surfaces of MTA and Geristore: cells on these materials were spindle shaped and well attached, with projections of lamellipodia, filopodia, blebs, and microvilli from their surfaces, reflecting good attachment to the materials.

Our findings with MTA are in agreement with the study of Balto 4 (2004) who reported good spread and a high density of attached human periodontal ligament fibroblasts to the surface of set specimens of MTA. Furthermore, Pérez, et al. ${ }^{16}$ (2003) also reported that osteoblasts and osteosarcoma cells attached well to both white and gray MTA in the short-term part of their study, although osteoblasts could not sustain their attachment to white MTA in the long-term part of their study (after 13 days). Raldi, et al. ${ }^{18}$ (2010) also found that MTA enabled the adhesion of fibroblasts to its surface. We have recently reported that one of the leached components of MTA was calcium ${ }^{3}$, and since calcium plays a major role in the process of fibroblast adhesion ${ }^{6}$, the effect of calcium is obvious regarding the attachment of cells to the surface of this material. The formation of hydroxyapatite when MTA is exposed to physiologic solutions has been strongly suggested to enhance its biological performance ${ }^{13}$.

In agreement with the findings of the current study, Al-Sabek, et al. ${ }^{2}$ (2005) reported that human gingival fibroblasts preferentially attached to Geristore with a morphology close to that of the controls, in comparison to the other rootend filling materials. Furthermore, Camp, et al. ${ }^{7}$ (2003) evaluated the quantitative attachment of human periodontal ligament fibroblasts to different root-end filling materials and showed that cellular attachment to Geristore was significantly higher than MTA, with an increase in cell count probably due to the proliferative effect of Geristore on the cells ${ }^{2,3}$.

Our study also showed that fibroblasts did not attach very well to the surface of the zinc oxideeugenol cements (IRM and Super EBA). These findings are in agreement with those of Al-Sabek, et al. ${ }^{2}$ (2005), who found that human gingival fibroblasts attached poorly to IRM and to those of Zhu, et al. ${ }^{24}$ (2000), who reported a similar outcome with osteoblasts, with cells having round structures with little or no processes extending from their surfaces. However, other studies found moderately well attached cells to Super EBA ${ }^{5,7}$. Furthermore, the results of the present study also showed poor attachment of the cells to the root surface of specimens of IRM and Super EBA. This could be linked to the presence of some component 
like eugenol that leached from the materials into the dentinal tubules of the root structure.

The surfaces of KetacFil and Retroplast showed the least cellular attachment. In agreement with our results, human gingival fibroblasts have been reported to show poor attachment to Ketac $\mathrm{Fil}^{2}$. On the other hand, Sasanaluckit, et al.20 (1993) reported no significant alterations in the morphology of cells in contact with Ketac Fil, when compared to the control. It has been reported that washing glass ionomer cements with distilled water and tissue culture media is a prerequisite to cellular attachment; without it cells do not attach ${ }^{23}$. In our experiment, cells were directly seeded over the material specimens without washing. Our results are also supported by those of Al-Sabek, et al. ${ }^{2}$ (2005), who found that human fibroblasts attached poorly to Ketac Fil.

In the current study, Retroplast displayed poor attachment characteristics, with cells exhibiting features of toxicity. It is possible that the higher concentrations of monomers leached to the immediate surroundings of the material were sufficient to cause a cytotoxic effect on the cells ${ }^{20,21}$. Noting that cells on the root surface exhibited features of good attachment further validates this conclusion. Currently, and to the best of our knowledge, there are no other reports on the use of Retroplast for in vitro attachment assays.

\section{CONCLUSION}

Overall, under the conditions of the current study, MTA and Geristore demonstrated the best cellular attachment to their surfaces among the materials investigated. IRM, Super EBA, Ketac Fil and Retroplast showed poor cellular attachment to their surfaces. IRM and Super EBA affected negatively the attachment of the cells to the root structure close to them.

\section{REFERENCES}

1- Al-Nazhan S. SEM observations of the attachment of human periodontal ligament fibroblasts to non-demineralized dentin surface in vitro. Oral Surg Oral Med Oral Pathol Oral Radiol Endod. 2004;97:393-7.

2- Al-Sabek F, Shostad S, Kirkwood KL. Preferential attachment of human gingival fibroblasts to the resin ionomer Geristore. ] Endod. 2005;31:205-8.

3- Al-Sa'eed OR, Al-Hiyasat AS, Darmani H. The effects of six root-end filling materials and their leachable components on cell viability. J Endod. 2008;34:1410-4.

4- Balto HA. Attachment and morphological behavior of human periodontal ligament fibroblasts to mineral trioxide aggregate: a scanning electron microscope study. J Endod. 2004;30:25-9.
5- Balto HA, Al-Nazhan S. Attachment of human periodontal ligament fibroblasts to 3 different root-end filling materials: scanning electron microscope observation. Oral Surg Oral Med Oral Pathol Oral Radiol Endod. 2003;95:222-7.

6- Baxter LC, Frauchiger V, Textor M, Gwynn I, Richards RG. Fibroblast and osteoblast adhesion and morphology on calcium. Eur Cell Mater. 2002;4:1-17.

7- Camp MA, Jeansonne BG, Lallier T. Adhesion of human fibroblasts to root-end-filling materials. J Endod. 2003;29:602-7. 8- Craig R, Hanks C. Restorative dental materials. St. Louis: Mosby-Year Book; 1997.

9- Hensten-Pettersen A. Comparison of methods available for assessing cytotoxicity. Int Endod J. 1988;21:89-99.

10- Kim S. Endodontic microsurgery. In: Cohen S, Burns R, editors. Pathways of the pulp. St. Louis: Mosby; 2002.

11- Lin CP, Chen YJ, Lee YL, Wang JS, Chang MC, Lan WH, et al. Effects of root-end filling materials and eugenol on mitochondrial dehydrogenase activity and cytotoxicity of human periodontal ligament fibroblasts. J Biomed Mater Res B Appl Biomater. 2004; 71:429-40.

12- Miranda RB, Fidel SR, Boller MA. L929 cell response to root perforation repair cements: an in vitro cytotoxicity assay. Braz Dent J. 2009;20:22-6.

13- Modena KC, Casas-Apayco LC, Atta MT, Costa CA, Hebling J, Sipert $C R$, et al. Cytotoxicity and biocompatibility of direct and indirect pulp capping materials. J Appl Oral Sci. 2009;17:544-54. 14- Morrow SG, Rubenstein RA. Endodontic surgery. In: Ingle JI, Bakland LK, editors. Endodontics. London: BC Decker Inc; 2002. 15- Oliva A, Della Ragione F, Salerno A, Riccio V, Tartaro G, Cozzolino $A$, et al. Biocompatibility studies on glass ionomer cements by primary cultures of human osteoblasts. Biomaterials. 1996;17:1351-6.

16- Pérez AL, Spears R, Gutmann JL, Operman LA. Osteoblasts and MG-63 osteosarcoma cells behave differently when in contact

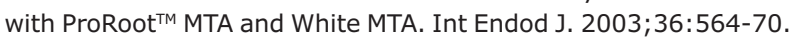
17- Pitt Ford TR. Surgical treatment of apical periodontitis. In: Ørstavik D, Pitt Ford T, editors. Essential endodontology. Oxford: Blackwell Science; 2004. p. 288-90.

18- Raldi DP, Mello I, Neves AC, Habitante SM, Miyagi SS, LageMarques JL. Attachment of cultured fibroblasts and ultrastructural analysis of simulated cervical resorptions treated with high-power lasers and MTA. Oral Surg Oral Med Oral Pathol Oral Radiol Endod. 2010;109:154-61.

19- Ribeiro DA, Matsumoto MA, Duarte MA, Marques ME, Salvadori DM. In vitro biocompatibility tests of two commercial types of mineral trioxide aggregate. Braz Oral Res. 2005;19:183-7.

20- Sasanaluckit P, Albustany KR, Doherty PJ, Williams DF. Biocompatibility of glass ionomer cements. Biomaterials. 1993;14:906-16.

21- Söderholm KJ, Mariotti A. Bis-GMA-based resins in dentistry: are they safe? J Am Dent Assoc. 1999;130:201-9.

22- Weston GD, Moule AJ, Bartold PM. A comparison in vitro of fibroblast attachment to resected root-ends. Int Endod J. 1999;32:444-9.

23- Yan F, Xiao Y, Li H, Haase H, Bartold PM. A comparison of the effects of two kinds of glass-ionomer cement on human gingival fibroblast attachment, proliferation and morphology in vitro. J Int Acad Periodontol. 2000;2:14-8.

24- Zhu Q, Haglund R, Safavi KE, Spangberg LSW. Adhesion of human osteoblasts on root-end filling materials. J Endod. 2000;26:404-6. 